\title{
The Influence of Incipient Ability, Indpendent Learning To Critical Thinking Ability Through Teaching Material Inquiry- Based
}

\author{
Waminton Rajagukguk \\ The Faculty of Mathematics and Natural Science of Medan State of University
}

\begin{abstract}
To foster mathematical teaching material inquiry based aided by multimedia that caused to upgrade critical thinking of High School Students (HSS) across North Sumatera as the focused purpose of this study. Implemented in North Sumatera from the year of 2016 to 2018 . The population covered overall high school students. The subjects were the high school students themselves. Technically picking sample on by exercising purposive random sampling that is pick on six HSS randomly with three HSS from public school and three HSS from private school. To perceive the influence of teaching material of mathematics inquiry-based aided by multimedia which is developed used designed research of quasi experiment with design control group post test only. Technically to turn in data used questionnaires, observation, and test. The data being analyzed with working out with technical descriptive analysis, examined $t$ and anova. The experiment of study found inquiry learning model in groups caused students are encouraged to express their thoughts and keeping others thoughts. Inquiry learning model aided by multimedia interacts with students' incipient mathematical ability to critical thinking ability. Students' incipient mathematical ability in low and high category rather used inquiry learning aided by multimedia, meanwhile for students' incipient ability of low rather used ordinary learning model or expository. Students critical thinking are more in medium category that is of $\mathbf{3 8 . 7 1 \% \text { , }}$ this case means that to upgrade critical thinking ability in this study its necessary to focus on one of the third limitedness in allowing more opportunities to students to think creatively.
\end{abstract}

Keywords: Incipient mathematical ability, Independent Learning, Critical Thinking Ability.

\section{INTRODUCTION}

Since Educational Unit Level Curriculum (EULC) enforced and curriculum 2013, were required critical in fostering appealing teaching material and diverse with choosing one learning model which can motivate the students to be active and participative in learning. Fostering material teaching its on teachers' accountability as tutor to their students in the class. By teachers' creativity in fostering teaching material will produce a meaningful learning teaching.

Teachers' creativity elevating skill process that students could have achieved in learning in particular with inquiry encouragement among of them are: 1) students formulate or develop a hypothesis from presented cases, 2) students will model the matters which has been presented orally or written, 3) students interpret and evaluate the ideas of mathematics, 4) students review the ideas of mathematics through conjecture and convinced principles, 5) students construct their owned knowledge openly to verity the truth of proposed hypothesis. From the skill process students will enable to draw a conclusion out of the available matters and enable to communicate openly orally or written. So, through learning by inquiry model students will be more active, creative and more skilled in developing mathematical 
communicative ability. Bruce and Well (in Hosnan, 2014:345) noted that "Inquiry Learning model attempts to teach diverse skills and scientific languages".

Inquiry learning is series of activity which emphasized on critical thinking process and analytically to seek and find themselves the answers of questioned matters. Thinking process itself usually done through ask and answer between teachers and students. In accord with concluded by Bruce and Weil (in Hosnan 2014:346) that; "Exercising of inquiry might increase knowledge of science, produce creative thinking ability, creativity in gaining and analyzing a data" whilst ordinary learning more emphasizing upon students not to seek and find themselves the concepts which caused students are often failing to recall.

So that inquiry learning can be more achieving expected goal, therefore in this model teachers are able to employ learning media which is demonstrated by teachers. Anyhow, most often teachers are found not using learning media when they teach a material that which is supposed to use learning media to support learning teaching process. By demonstrating the use of learning media of mathematics, teachers can stimulate aroused motivation in the students themselves to learn next material. Students who are curious and want to know more about learnt material will keep going to exert to learn next material. Therefore one of the media that might be used in learning mathematics is employing teaching material of mathematics inquirybased aided by multimedia will foster logical thinking pattern, systematically, objective and rationally so it is competent to form students critical thinking.

One of a way which is regarded appropriately to support the exertion is through studying development. Through this study will be developed mathematical learning design inquirybased aided by multimedia to upgrade high school students critical thinking.

\section{Inquiry Learning Model}

\section{BIBLIOGRAPHY STUDY}

Inquiry learning is a series of learning activity emphasized on students critical thinking and analytically to search and find themselves the answers of a questioned matters. Thinking process itself usually treated by asking and answering between teachers and students. This learning its often called heuristic strategy, literally from Greek, that is heuriskien which means I found it (Hosnan, 2014:341)

In pursuance of Piaget, inquiry is an encouragement that to prepare students on situation to do experiment themselves widely in order to see what happen, craved to do something, propose questions, and find themselves the answers, and to connect answers of one and another, to compare what was found with what other students found.

In comply with Eggen \& Kauchak (in Trianto, 2009:172) the phase of inquiry learning is illustrated on the table 1 below. 
Table 1

Phases of Inquiry Learning

\begin{tabular}{|c|c|}
\hline Phase & Teacher Behavior \\
\hline $\begin{array}{l}\text { 1. Present questions } \\
\text { or matters }\end{array}$ & $\begin{array}{l}\text { Teachers guide students to identify matters written } \\
\text { on board. Teachers divide students into groups. }\end{array}$ \\
\hline $\begin{array}{l}\text { 2. Provide } \\
\text { Hyphothesis }\end{array}$ & $\begin{array}{l}\text { Teachers give opportunity upon students to pour } \\
\text { out their mind in hypothesis form. Teachers guide } \\
\text { students in determining hypothesis which is } \\
\text { relevant with the matters and to prioritize the } \\
\text { hvnothesis that which one to hecome the nriority of }\end{array}$ \\
\hline 3. Design Experiment & $\begin{array}{l}\text { Teachers allow opportunity to students to } \\
\text { determine the steps which are fit to that hypothesis } \\
\text { that will be treated. Teachers guide students to sort } \\
\text { the steps of experiment }\end{array}$ \\
\hline $\begin{array}{l}\text { 4. Treat Experiment } \\
\text { to have information }\end{array}$ & $\begin{array}{l}\text { Teachers guided students to get information right } \\
\text { from experiment. }\end{array}$ \\
\hline $\begin{array}{l}\text { 5. Collect and analyze } \\
\text { data }\end{array}$ & $\begin{array}{l}\text { Teachers allow each opportinities to groups to } \\
\text { present data study result which turned in. }\end{array}$ \\
\hline 6. Provide Conclusion & Teachers guide students in providing conclusions \\
\hline
\end{tabular}

And then Hinrichsen (1999) also appended that inquiry consisted of two main means they are inquiry as a core of scientific exert and inquiry as a strategy to teaching and learning mathematics. Gulo (in Trianto, 2009:168) not only as his own experiment or as a scientific exert more emphasizing that Inquiry to develop a whole any potential, encompassing emotional development and the skills of inquiry is a process which is begun with formulating matters, formulating hypothesis, collecting data, analyzing data, and providing conclusion".

Trianto (2009:172) concluded, there were five steps reached in implementing inquiry learning, they are:

1. To formulate cases to be solved by students

2. To ascertain temporary answer or more known with hypothesis

3. To search information, data, facts which are needed to answer hypothesis or cases

4. To draw conclusion of answers or generalization

5. To apply the conclusion

Activity within the steps, the teachers or students have each prominences. According to Sani (2014:91), as for teachers activity and students in implementing inquiry is illustrated on table 2 below: 
Table 2

The Activity of Teachers and Students in Implementing Inquity

\begin{tabular}{|c|c|}
\hline Teachers' Behavior & Students' Behavior \\
\hline $\begin{array}{l}\text { - To encourage to think, ask, and } \\
\text { discuss } \\
\text { - To facilitate debate and } \\
\text { discussion } \\
\text { - To provide various way to } \\
\text { investigate } \\
\text { - To be acting like a mate in } \\
\text { investigation } \\
\text { - Arousing student's interest to be } \\
\text { active to do investigation and } \\
\text { searching new information } \\
\text { - To keep condusive environment } \\
\text { To emphasize on how to } \\
\text { understand learning material, not } \\
\text { on what should be known from } \\
\text { that lesson. }\end{array}$ & $\begin{array}{l}\text { - To do observation, to turn in and } \\
\text { to interpret data } \\
\text { - To formulate hypothesis, to } \\
\text { design, and to do experiment to } \\
\text { examine phenomena. } \\
\text { - To connect independent and } \\
\text { dependent variable } \\
\text { - To use reasoning ability } \\
\text { - To draw conclusion based on data } \\
\text { - To defend conclusion based on } \\
\text { data }\end{array}$ \\
\hline
\end{tabular}

\section{Media in Learning}

The word of Media from Latin, that is medius literally means medium, mediator or comebetween. Media is a mediator or postman from sender to recipient of messages (Hamdani, 2011) Gerlach and Ely noted that media when it is sensed the outline, media is human being, material, or scene which constructing condition so that students are able to obtain knowledge, or attitude.

In virtue of behaviorism, learning is a teachers' effort to form expected behavior with providing environment or stimulus (Hamdani, 2011)

Learning media may be stated as an instrument that can stimulate students that of learning ensued. Media is not only sighted as TV, radio, computer, but including human being as well as resources of learning or activity, like discussion, seminar, stimulation, and so on (Hamdani, 2011).

Learning media functions as: (1) facility to manifest effectual learning situation, (2) the part of integral from a whole learning process, (3) to accelerate learning process, (4to upgrade the process of learning teaching quality, (5) to catch the goal and teaching material is more easier and more rapidly (Hamdani, 2011).

Therefore learning media can be concluded is everything that may distribute messages, stimulate thoughts, senses, and the will, in order to promote students' habit in learning process.

\section{METHOD OF STUDY}

This study is a research over developing phases of learning model entailing procedures of learning model development of Thiagarajan, Semmel \& Semmel . Referred to 4-D model (four D-Model, which consisted of Define, Design, Develop and Disseminate. The fishbone diagram 
that illustrates the model of learning process and expected achieved target, as in figure 1 below:

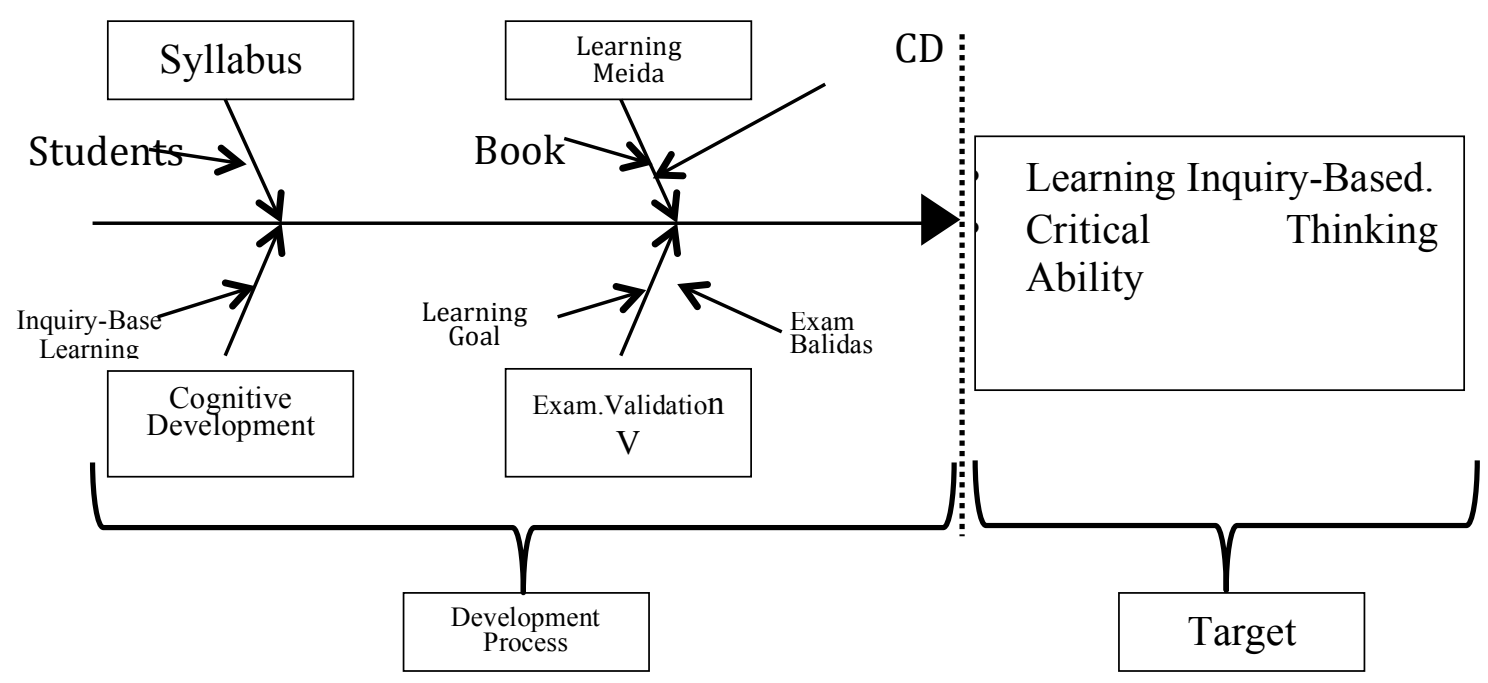

Fig 1: Fishbone Learning Model Study

\section{RESULT AND DISCUSSION}

This result of experimental research discussed about the findings based on factors which bound in the study as: learning factor, incipient ability factor, critical thinking of mathematics factor, the factor of independent learning and limitedness of study to be a next reference. Those cases will be described as follows:

\section{Learning Factor}

The characteristic of inquiry learning model is inventive learning in accord with actively searching knowledge, self endeavor to find solving problem and accompanied knowledge, proceeds knowledge which is truly meaningful. That thing is visible from inquiry learning application with learning activity which implemented in group with heterogeneous ability. Learning activity implemented with assigning the activity of discussion in the form of a hand out of students activity sheet (SAS). Subsequently will be exposed students' activity in solving problems around the material of mathematics of quadratic function aided by multimedia.

In the beginning, students felt being alienated with inquiry learning model aided by multimedia which implemented because they usually learn with rordinary learning that more accentuate teachers activity to describe learning material from the beginning to the end even that presentation never touch yet of learning mathematics connected with ICT. Inquiry learning model aided by multimedia its perceptible new to High School Students, but with the teachers acting as facilitator, ultimately students enabled to accomplish well all problems listed in Students Activity Sheet (SAS). The end result of the process of group discussion, students are able to provide true answers and they present them before the class.

\section{Students' Incipient Ability (SIA/KAM) Factor}

By grouping SIA/KAM (High, Medium, Low) formed as follows to students who have score SIA/KAM $\geq \bar{X}+S D$ grouped in high mathematical ability, students who have score SIA/KAM $(\bar{X}-S D<K A M<\bar{X}+S D) \quad$ grouped in medium mathematical ability, while 
students who have score SIA/KAM $\leq \bar{X}-S D$ grouped in low mathematical ability demonstrated on table 3 as follows:

Table 3. Description of Students Grouping Based on SIA/KAM

\begin{tabular}{|c|c|c|}
\hline CategoryKAM & Statistic & $\begin{array}{c}\text { Learning } \\
\text { Inquiry based on Autograph }\end{array}$ \\
\hline \multirow{4}{*}{ High } & S & 6 \\
\cline { 2 - 3 } & Average & 77.83 \\
\cline { 2 - 3 } & Standard Deviation (SD) & 1.16 \\
\hline \multirow{3}{*}{ Medium } & S & 23 \\
\cline { 2 - 3 } & Average & 60.48 \\
\cline { 2 - 3 } & Standard Deviation (SD) & 6.78 \\
\hline \multirow{3}{*}{ Low } & S & 5 \\
\cline { 2 - 3 } & Average & 36.6 \\
\cline { 2 - 3 } & Standard Deviation (SD) & 5.89 \\
\hline
\end{tabular}

From the recapitulation on table 3 reflected that generally average score of three groups on the category of SIA/KAM (high, medium and low) has the quality of SIA/KAM that normally distributed, this thing reflected to high SIA/KAM and low SIA/KAM that many students are almost alike at the mean time to medium SIA/KAM there is 23 students. This case is sufficient to qualify to give learning. But, if it is discerned from each of category of SIA/KAM, the quality of average score of SIA/KAM of each groups of students is relatively different. This case is acceptable because students are grouped based on the category of high, medium, low SIA/KAM.

Based on manual count acquired learning factor and SIA/KAM showing off that Fcount ( $=3.51)$ $>$ Ftable $(=3.14)$ means there is interaction between learning with students incipient ability toward students' mathematical critical thinking ability. For more clear illustrated on figure 2 below:

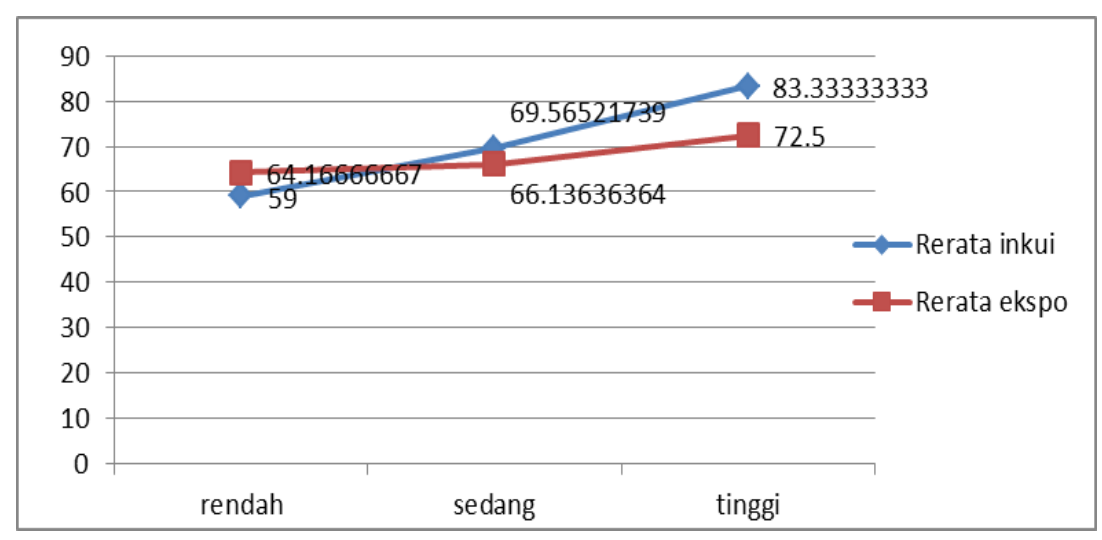

Fig 2. Interaction between Learning Model with KAM toward Students' Mathematical Critical Thinking Ability

On the figure 2 above vividly exposed that there is interaction or association between learning model with students' incipient ability, so on medium and high rather use inquiry learning model aided by multimedia, meanwhile for those who are low ability rather using ordinary learning model or expository. 


\section{The factor of Mathematical Critical Thinking Ability}

The sort of test used is descriptive test consisted of 5 questions. Qualitatively the extent of students' critical thinking of mathematics toward material of quadratic function aided by multimedia on the table 4 below;

Table 4. Test Result of Students' Mathematical Critical Thinking Ability

\begin{tabular}{|c|c|c|c|c|c|}
\hline No & $\begin{array}{l}\text { Range of } \\
\text { Score }\end{array}$ & $\begin{array}{c}\text { Total } \\
\text { Students }\end{array}$ & Percentage & Category & Accomplishment \\
\hline 1. & $\begin{array}{l}0 \leq \mathrm{KBKM} \\
<45\end{array}$ & 0 & $0 \%$ & Very Low & \multirow{2}{*}{$16.11 \%$} \\
\hline 2. & $\begin{array}{l}45 \leq \mathrm{KBKM} \\
<65\end{array}$ & 5 & $16.13 \%$ & Low & \\
\hline 3. & $\begin{array}{l}65 \leq \mathrm{KBKM} \\
<75\end{array}$ & 12 & $38.71 \%$ & Medium & \multirow{3}{*}{$83.89 \%$} \\
\hline 4. & $\begin{array}{l}75 \leq \mathrm{KBKM} \\
<85\end{array}$ & 11 & $35.48 \%$ & High & \\
\hline 5. & $\begin{array}{l}85 \leq \mathrm{KBKM} \\
\leq 100\end{array}$ & 3 & $9.677 \%$ & Very High & \\
\hline
\end{tabular}

Explanation:

SMCTA: Students' Mathematical Critical Thinking Ability

\section{Students' Independent Learning Factor}

Students' Independent Learning is meant in this study is to cover five indicators they are; 1) learning initiative, 2) to set target and learning goal, 3) to monitor, manage and control learning progress, 4) to harness and seek relevant resources and 5) to evaluate process and learning result.

In connection with those indicators the students' independent learning in harmony with learning theory of Bruner who regarded that inventive learning in comply with searching knowledge actively by human being, doing itself to find solving problem and with accompanied knowledge, proceeds truly meaningful knowledge (Defantri, 2009).

In agree with learning theory Vygotsky too, elucidated that learning process occurred on two phases: first phase ensued at the moment of collaboration with others, and next phase implemented individually which in it that happened internalization process. During that process interaction occurred, between teachers-students or between students, ability like to examine the truth of statement of others, to negotiate, and to adopt thoughts to each other may develop. From the insight of Vygotsky might be concluded that in learning process, might be implemented in groups or individually. Implication and knowledge development by students impacted by social factor. The following essence from the interview with students as follows; (1) in my opinion the independent learning can spur us to cause curiosity on cases which left unsolved yet and to find the most right answer so we can reflect to see whether I am able or not for this material, (2) in solving the problem I often find difficulties probably because of oblivious factor to recheck whether the questions which I worked it out are true so sometimes my score found unsatisfied but its becoming my evaluation when solving problem. 


\section{The Limitedness of Study}

Upon this experimental study it is possible implementation and respondents are human being who are not free from flaws and frailty because of inevitable and uncontrolled things which might be influencing of results of research, so in this study it is unveiled some limitedness of study in inquiry learning model aided by multimedia among of them:

1) In time of implementation of group discussion, in the beginning of learning the researcher as a teacher must have exerted to motivate students so that discussion will be effectively and not monopolized by certain students only, students are allowed a controlled freedom. This manner is not an easy work. Beside that the smart student who is expected to be able to lead his/her group not sound good to conduct the run of discussion. To cope with this problem, the team of research will entrust or impose guidance to the smart student within its group to manage the session of discussion and motivate other students to be actively to contribute relevant opinions/thoughts in conjunction with materials being learned. Students are required proactively casting and answer discussion within the group.

2) In time of class discussion, in light of a bit time allocated, in the beginning that inquiry learning model aided by multimedia the researcher as a teacher is often falling short of time on this session, so taking much time into group discussion session right in time of doing assignment which was given on Students Activity Sheet (SAS). Therefore the discussed cases more get lessened. To cope with the case, the researcher as a teacher is to decide to choose questions which considered are really complicated and just pointing out some students to speak up thoughts/question but every students have equal opportunity to ask, put forward ideas or thoughts during the time being encouragement.

3) Afterwards at time of provoking questions, to plan solution, and to find another way in solving problem listed in SAS, in the beginning the students are often running time out to find another way in solving problem because they are busy to answer the questions. Moreover their work ought to turn in to be scored by researcher. In order to cope with this manner, researcher not too imposing many questions but to pick on some questions which is enough to represent material that is being learned in comply with expected indicator.

4) Indeed the instrument has passed examination its validity and reliability yet the instrument just to measure critical thinking ability, however not be able yet to measure learning process which students implemented to get learning result as a whole.

\section{CONCLUSION}

Based on the analyzed data results and findings of research along with learning experiment by inquiry model aided by multimedia to be concluded as follows:

1) Implication of inquiry learning model in groups caused students are encouraged to express their thoughts and taking others thoughts, to keep democratic attitude and to evoke conveniences in learning mathematics. Teacher is regarded as a learning mate, mediator, facilitator to bring about consequence into teachers to be more understanding the weakness and strong of the teaching material students' individual characteristic ability. If this things are kept doing continuously will bring up positive impact over teachers' knowledge in the future.

2) Inquiry learning model aided by multimedia is interacting with students' incipient mathematical ability toward critical thinking ability. Students' incipient ability in medium category and high rather to use inquiry learning model aided by multimedia, meanwhile as for students' incipient ability that who are low rather use ordinary learning model or expository. This thing to be a serious attention on low KAM category 
to another model. Learning activity implemented by imposing activity discussion in a form of SAS handed out more to students who are low ability, such as in a form of questions which guides or in a form of hints so the problem can be overcome.

3) The students who are having Critical thinking ability are more in medium category that of $38.71 \%$, this things meant to upgrade critical thinking ability within this study its necessary to pay attention as one of them the third limitedness in allowing more opportunities to think creatively.

\section{RECOMENDATION}

Based on inferences above, the researcher' recommendation as follows:

1) The findings of this study can be used for any researcher or teachers in order to know the related factors such as, learning factor, incipient ability factor (KAM), mathematical critical thinking ability factor, independent learning factor and limitedness study to be a reference for the next.

2) In solving problem the students are necessary to be accompanied to offer support at once, so that students reached the concept, able to understand, explaining concept and non-concept therefore learning becomes meaningful.

\section{THE EXPRESS OF GRATITUDE}

To Directorate of Study and Dedication to The Ministry of High Educational and Culture Directorate General, in comply with Agreement of Assigned Implementing Study Continued Competitive Grant Number: 054/SP2H/LT/DRPM/II/2016, dated on February 17, 2016.

\section{BIBLIOGRAPHY}

Defantri, (2009). Pembelajaran Matematika Di Sekolah. [Online] Tersedia:http://defantri. blogspot.com/2009/05/pembelajaran-matematika-di-sekolah.html. (11 April 2009)

Gulo, (2008), Strategi Belajar Mengajar, Gramedia, Jakarta.

Hamdani. 2011. Strategi Belajar Mengajar. Bandung: Pustaka Setia.

Hosnan, (2014), Pendekatan Saintifik dan Kontekstual dalam Pembelajaran Abad 21, Ghalia Indonesia, Bogor.

Hinrichsen D., Robey B. and Upadhyay U. D., Solutions for a Water-Short World. Chapter 3: The Coming Era of Water Stress and Scarcity. Population Reports, Series M, No. 14. Baltimore, Johns Hopkins School of Public Health, Population Information Program, 1998

Sembiring, T. (2010). Meningkatkan Kemampuan Penalaran dan Komunikasi Matematis Siswa Sekolah Menengah Atas Melalui Pembelajaran Analitik Sintetik. Tesis pada PPS UPI:Tidak Diterbitkan.

Sani, R.A. (2014), Pembelajaran Saintifik untuk Implementasi Kurikulum 2013, PT. Bumi Aksara, Jakarta.

Trianto, (2009). Mendesain Model Pembelajaran Inovatif Progresif: Konsep, Landasan, dan Implementasinya pada Kurikulum Tingkat Satuan Pendidikan (KTSP). Kencana. Jakarta. 